\title{
MUSES-C カプセル全機周り 輻射加熱環境の工学的評価*1 Assessment of Radiative Reentry Environment around MUSES-C Capsule
}

\author{
藤 田和 央 $^{* 2} \cdot 大$ 津 広 敬*3 $\cdot$ 山田哲 哉*2 $\cdot$ 安部 隆 $士^{* 2}$ \\ Kazuhisa Fujita, Hirotaka Otsu, Tetsuya Yamada and Takashi Abe
}

Key Words : High Enthalpy Flows, Heat Transfer, Radiation, Nonequilibrium Aerothermodynamics, Reentry

\begin{abstract}
Forebody and aftbody radiative heating rates of the MUSES-C asteroid sample return capsule have been assessed along the reentry trajectory from an engineering standpoint. Nonequilibrium hypersonic flows around the capsule with ablation of the thermal protection system involved were determined by CFD calculations, while the radiative heat transfer was computed by the radiation code SPRADIAN in a non-coupled manner with the flow analysis. In order to take into account much uncertainty in the thermal relaxation, chemical reaction, and ablation models used in the flow analysis, parametric studies were performed by changing these models to obtain the conservative estimation of the radiative environments. The radiative heat flux was found to be considerably affected by the ablation model, especially in the aftbody region of the capsule.
\end{abstract}

\section{1. は じめに}

MUSES-C ミッション ${ }^{1)}$ は宇宙科学研究所が計画する小 惑星サンプルリターンミッションであり，地球接近型小惑星 1998SF36 をターゲットとして 2003 年春期に M-V 5 号機 で打上げられ，2007 年夏に地球へ帰還する予定である.八 イライトとなる地球再突入フェーズでは, 小惑星サンプルを 内蔵した再突入カプセルが衛星から分離され, 惑星間軌道か ら直接再突入する.このとき再突入の対地速度は $12 \mathrm{~km} / \mathrm{s}$ を越え, カプセルは再突入時にアポロの数倍という厳しい 空力加熱環境にさらされると予想されている .この厳しい 加熱環境から機体を守るため, 熱防御システム (thermal protection system; TPS) としてカーボン系のアブレータ 材料を採用している．TPS の設計においては，カプセルの 安全性を高めるにはアブレータ厚みを増加させる必要があ るが, 質量を低減させるにはできるだけ厚みを薄くする必 要があるという，相反する条件を最適化させなければならな い. 弚のためには再突入軌道上での加熱環境の正確な評価 が必要であり, 乥の加熱環境の評定精度が TPS の信頼性向 上や設計の最適化に大きなインパクトを与えることになる．

MUSES-C カプセルの加熱環境を評価する上で重要な項 目の一つが, 輻射加熱の寄与である . 一般に衝撃波速度が $10 \mathrm{~km} / \mathrm{s}$ を越えると衝撃波背後の気体の輻射強度は急激に 増加し2)，MUSES-C カプセルの加熱率に占める輻射加熱 の寄与は無視できないことが分かっている .これまで行わ

\footnotetext{
*1 (C) 2003 日本航空宇宙学会

平成 14 年 12 月 11 日原稿受理

$* 2$ 文部科学省宇宙科学研究所

$* 3$ 静岡大学工学部
}

れた研究 ${ }^{3 \sim 6)}$ により，輻射加熱の特性について多くの重要 な結果が得られている.しかしこれらの研究では, 検討し た事例が少ないため工学的な情報は不十分であり，またカ プセルの再突入軌道について近年なされたいくつかの再検 討結果が反映されていないため, 実際の輻射環境との相違 が色惧される．弚こで本稿では，最新のミッション計画を 反映し，また工学的に有用な情報を与えることを目的とし て , カプセルの輻射環境の評価を行った .

輻射環境を評価する上では, どのようなモデルを用いる かが重要である.近年 , 流れ場とアブレーションの相互作 用を考慮した連成解析 を考慮した解析 ${ }^{5,8)}$ も行われるようになってきた .このよう な高レベルの連成解析は, 乥れ光れの現象が結果として機 体の加熱率にどのような影響を与えるかを判定する上では 非常に重要であるが，定量的な結果を光のまま設計に反映 することは，現状では難しいように思える.弚の理由は，乥

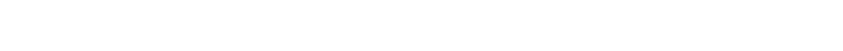
れに対する結果の感度の検証が不十分なためである . 例え ば，流れ場の解析に広く用いられる熱的・化学的非平衡モデ ル ${ }^{9 \sim 13)}$ は, 地球周回低軌道 (low earth orbit; LEO) から の再突入に関しては信頼性が高いと考えられてきたが, 実 際には実験的な検証が不十分であるだけでなく，経験的な パラメータをLEO からの再突入条件に適合させてあるた め, MUSES-C の再突入環境をどの程度の精度で評価でき るのか疑問である.事実，幾つかの実験ではこれらのモデル が正確ではないことを示唆する結果が得られている ${ }^{2,14 \sim 16)}$.

Otsu らの一連の研究によれば $3,4,6)$, 輻射加熱は解析に 用いる熱的緩和・化学反応等のモデルに敏感で, 解析に用 いるモデルの精度か輻射加熱を評価する上で重要であるこ 
とが分かっている. カプセルの設計という工学的な立場に 立てば，解析モデルに含まれる不確実性まで考慮した上で， これを越えないと期待できる (即ち安全側の) 加熱率の見 通しが得られるような解析を行うことが重要である. 以上 の理由から本稿では, 解析モデルが持つ不確実性について 検討して得られた Otsu らの成果と指針の上に立ち，できる だけ簡素な解析システムを用いてパラメトリックな解析を 行うという手法で, 輻射加熱環境の総合的な評価を行った .

\section{2. 解 析モデル}

2.1 再突入軌道 再突入軌道はカプセルの空力係数デー タベースに基づいた再突入軌道解析により決定した . TPS の設計を行う際の再突入軌道として, ミッションのノミナ 儿軌道とは別に飛行環境として光れを内包する形で, 最大 加熱率が最大になる軌道 (深い経路角) と総加熱量最大 (浅 (経路角) の二つの TPS 評価軌道を設定した .これらの 軌道は, 惑星間遷移軌道計画において決まる再突入速度か ら，種々の軌道の分散を経路パラメータに集約する形で龹 の両側を採用したものである ${ }^{17)}$. 特に総加熱量最大軌道が アブレータ裏面の温度を決めることになるので, 本研究で は後者の軌道を用いた . この場合の再突入初期条件は, 高 度 $200.0 \mathrm{~km}$, 対地速度 $12.20 \mathrm{~km} / \mathrm{s}$, 対地経路角 $-12.0 \mathrm{deg}$ である .なお大気モデルとしては 1962US 標準大気モデル を用いた . 予測される飛行高度と飛行速度の $t=20$ から 130 秒まで履歴を第 1 図に破線で示す.

2.2 流れのモデル カプセル周りの流机場は軸対称と仮 定し, 軸対称 2 次元の Navier-Stokes 方程式を解くことに より決定した . 流れを構成する化学種として， $\mathrm{N}_{2}, \mathrm{O}_{2}, \mathrm{~N}$, $\mathrm{O}, \mathrm{NO}$ およびその一価のイオンと電子から構成される大 気 11 種と，アブレーション生成物として $\mathrm{C}, \mathrm{C}_{2}, \mathrm{C}_{3}, \mathrm{CN}$, $\mathrm{CO}, \mathrm{CO}_{2}$ の 6 種を考慮した . 水素系の生成物に関しては炭 素系の生成物と比較して少量であり，機体の加熱率への影 響があまり認められなかったため本解析では割愛した . 温 度モデルとして, 重粒子の並進温度 $T$, 分子の回転温度 $T_{\mathrm{r}}$, 振動温度 $T_{\mathrm{v}}$, および電子励起-電子の並進温度 $T_{\mathrm{e}}$ を独立に 取り扱う 4 温度非平衡モデルを用いた ${ }^{18)}$. この理由は， $T_{\mathrm{r}}$ と $T_{\mathrm{e}}$ の非平衡を考慮することにより衝撃波背後で $T_{\mathrm{e}}$ が 2 温度モデル ${ }^{13)}$ で予測されるよりも若干高くなり，結果的に 輻射加熱率の值が大きくなる (即ち安全側の解析が行える) ためである．なお，対流加熱に関しては 4 温度モデルと 2 温度モデルでほとんど差異が認められなかった .

各化学種の内部エネルギーは, 各内部モードの励起準位 分布を Boltzmann 分布で近似し, 分子の回転モードにつ いては無限準位の rigid-rotator モデルを, 振動モードにつ いては解離準位までの harmonic oscillator モデルを用い て計算した . 電子励起モードについては, 分子については 兴の寄与が小さいため無視し, 原子については適当な打切 り準位までの励起を考慮する Park の方法 ${ }^{12)}$ にならい計算 した . 分子イオンについては微量であり, 弚の内部エネル ギーが流体の全エンタルピに占める割合は小さいため, こ れを無視した .
内部モードの熱的緩和過程は，1）分子の振動-重粒子の並 進モードの緩和については Millikan-White-Park モデル ${ }^{13)}$ を，2）電子の並進-重粒子の並進モードの緩和については デバイ遮蔽されたクーロン弾性衝突によるエネルギー交換 モデル $\left.{ }^{12,19)} を ， 3\right)$ 分子の回転-重粒子の並進モード緩和に ついては回転衝突数に Parker モデル20) を用い，4) 電子の 並進一分子の振動モード緩和については Mertens モデル ${ }^{21)}$ を用いた .ただし 3) において， $\mathrm{N}_{2}$ に関しては Lumpkin らの提案 ${ }^{22)}$ に従って $\left(Z_{\infty}, T^{*}\right)=(18,91.9)$ を, $\mathrm{O}_{2}$ に関 しては Lordi-Mates ${ }^{23)}$ の値 $(16.5,113.5)$ を, NO に関し てはBoyd の提案 ${ }^{24)}$ に従い $(7.5,119)$ を用いた .4)につい ては $\mathrm{N}_{2}$ についてしかデータが与えられていないため， $\mathrm{O}_{2}$ については $\mathrm{N}_{2}$ のものを便宜上代用している.ただし， $\mathrm{O}_{2}$ は衝撃波背後て速やかに解離されるため, $e-\mathrm{O}_{2}$ の振動モ一 ドの緩和モデルの差異が衝撃波背後の電子温度分布に与え る影響はほとんどない .

非平衡化学反応は, 空気 11 種に関して Park の反応モデ ル ${ }^{13)}$ を, 炭素系生成物については Blottner の反応モデル9) を用いた . 4 温度モデルを用いる場合, Park の分子解離反応 モデルで用いられる幾何平均温度 $T_{\mathrm{a}}$ をどう定義するかが問 題となるが，ここでは文献 18) に従って $T_{\mathrm{a}}=T^{0.3} T_{\mathrm{r}}^{0.3} T_{\mathrm{v}}^{0.4}$ とした . Park モデルでは, 逆反応の速度係数を平衡定数か ら詳細釣り合いの原理に基づいて計算するが, 平衡定数に 対する既存のカーブフィット ${ }^{11,12)}$ の高温域における精度が 悪いため, 本解析では平衡定数を再計算して新たなカーブ フィットを作成している，ところで, 分子の解離 (あるいは 再結合) の際に失われる (あるいは獲得される) 内部エネル ギーをどう定義するかが , 衝撃層の振舞いや輻射加熱率の 計算結果に大きな影響を与えることか指摘されている ${ }^{3,6)}$ 。 本解析では工学的に安全側の解析を行う立場から, 輻射加 熱率がもつとも大きく計算されるモデルとして ${ }^{6}$ ), 解離 (再 結合) の際に失われる (蒦得する) 振動エネルギーが基底状 態からの解離エネルギー $D_{0}$ の 0.3 倍であるという選択的 解離モデルを用いた . 同樣の検討から, 解離 (再結合) の際 に失われる (獲得する) 回転エネルギーについては $D_{0}$ の 0.55 倍とおいた ${ }^{25)}$.

流体内の輸送過程については，モデルにより熱流束に若 干の違いの生じることが確認されている ${ }^{26)}$. 本解析では Chapmann-Cowling の一次近似に基づいた Hirschfelder らの方法 ${ }^{27)}$ を用いて拡散流束，並進モ一ドの熱伝導度，お よび粘性係数を計算した . ただし Devoto の方法 ${ }^{28)}$ を用い て流束マトリクスを修正し, 荷電粒子の両極性拡散を正確 にモデル化している .この理由は, 衝撃波直後での電子の 分布を正確に取扱うためには, 荷電粒子について両極性拡 散過程を考慮する必要があるためである ${ }^{15)}$. 分子の回転 , 振動モードに関する熱伝導度は Brokaw のモデル ${ }^{29)}$ を用い た . 電子励起モードの熱伝導は他の熱伝導過程と比較して 非常に小さいため，これを無視した .

輸送過程を計算する上で重要なもう一つの要素が, 計算 に用いる衝突積分の精度である. MUSES-C 周りの流れ場 では低温度 ( 200 K) から非常に高温度 ( 70,000 K) ま 
で環境が変化するため, 広い温度範囲で正確に定義された 衝突積分が必要である. 広く用いられているのは文献 11) のものであると考えられるが , これは $30,000 \mathrm{~K}$ までしか 定義されておらず, また低温度側 $(<500 \mathrm{~K})$ での精度も悪 い19,30). 特に電子と分子の間の衝突積分に関しては精度が 著しく悪い，乥こで本解析では，中性粒子間，および中性 粒子と荷電粒子の間の衝突に関しては, Capitelli らの最新 の衝突積分 ${ }^{30)}$ を用いた . 荷電粒子間の衝突に関しては, デ バイ遮蔽されたクーロン衝突近似に基づく Fertig らの衝突 積分 ${ }^{19)}$ を用いた。

ところで，アブレーション生成物に関しては，上記の緩 和過程や輸送過程を計算するのに必要なデータが不完全な 場合が多い(特に高温でのデータが不十分である). 㫕こ で本解析では, 緩和過程や輸送過程の計算においてデータ が存在しない場合，衝突過程において C は N-like であり， $\mathrm{C}_{2}, \mathrm{C}_{3}$ ，および $\mathrm{CN}$ は $\mathrm{N}_{2}$-like であり， $\mathrm{CO}_{2}$ および $\mathrm{CO}$ は NO-like であるとして衝突積分, 緩和時間, および衝突数 を決定した 。

2.3 壁面条件とアブレーションモデル MUSES-C カ プセルで用いているカーボン系アブレータの壁面からの吹 出しは, 主としてパイロリシスガス (pyrolisys gas; モル 比で $\mathrm{C}: \mathrm{H}: \mathrm{O}=2.85: 7.54: 1.00)$ によるものと, カー ボン層の酸化および昇華によるものから構成される . パイ ロリシスガスの組成なども含めて, アブレーションの機構 には不明な点が多く, 詳細なモデルを用いても精度に疑問 が残るため, 本解析では以下に述べる簡易なモデルを用い てパラメトリックな解析を行うこととした .

まず準一次元熱伝導アブレーション解析コード31) をベー スに, MUSES-Cの TPS 評価軌道に沿ってアブレーション 解析を行い, パイロリシスガスの吹出しレートとカーボン 層の質量損失レートをあらかじめ計算しておく . 次にパイ ロリシスガスのモル比からガスに含まれる C , O の質量流 量を計算し，このCとカーボン層の質量損失レートを加え てCの吹出し総量を見積もる.最後にパイロリシスガスに 含まれる $\mathrm{O}$ と，主流から拡散により壁面へ供給される $\mathrm{O}$ ， $\mathrm{O}_{2}$ はすべて $\mathrm{C}$ と結合して CO として壁面から衝撃層内部 への吹出しとなり, 残りの炭素はすべて $\mathrm{C}_{3}$ として衝撃層 内部入吹き出すと仮定して, 壁面からの $\mathrm{CO}, \mathrm{C}_{3}$ の吹出し レートを決定する．実際には，本解析で検討した条件下で は壁面近傍で圧倒的に C 過多であり, また吹出し量の絶対 值が大きいため主流から $\mathrm{O}$ がほとんど壁面へ供給されず， $\mathrm{CO}$ の吹出し量は実質的にはパイロリシスガスに含まれる 酸素の量で決まることが分かった . また $\mathrm{C}_{3}$ は衝撃層内で非 常に速やかに解離または酸化されるため, 結局輻射加熱率 は吹き出すガスの組成に対して感度が低いことも分かった．

壁面での化学種 $i$ の質量流量バランスは, 壁面に垂直な 方向について以下のように表される.

$$
d_{i}+\rho_{i} u=\sum J_{j i}+\dot{m}_{i}
$$

ここで $d_{i}$ と $\rho_{i}$ はとれ光れ化学種 $i$ の拡散流束と密度, $u$ は主流の速度, $J_{j i}$ は壁面上での化学反応により化学種 $j$
から生成する化学種 $i$ 質量流量, また $\dot{m}_{i}$ は壁面内部か ら単位時間あたり供給される化学種 $i$ の質量である.壁面 での再結合レートは

$$
K_{i}=\rho_{i} \gamma \sqrt{R_{i} T_{\mathrm{w}} / 2 \pi}
$$

で与えた ${ }^{9)}$.ここで $\gamma$ は再結合係数， $R_{i}$ は化学種 $i$ の気 体定数， $T_{\mathrm{w}}$ は壁面温度である.これらの式と壁面での運 動量バランス

$$
\frac{\partial p}{\partial n}=-\rho u \frac{\partial u}{\partial n}
$$

および状態方程式 $p=\sum \rho_{i} R_{i} T_{\mathrm{w}}$ から壁面上でのすべての 物理量が決まる．ここで $p$ は圧力, $\rho$ は全密度, $n$ は壁面 に垂直な方向にとった座標である．ただし壁面での接線方 向の速度は 0 とし, また本解析では $T_{\mathrm{w}}$ は一定值として与 えた . また, 吹出し量は前面にわたって一定であると仮定 して計算を行った．この条件は後に示すように，結果的に 衝撃層厚みを増加させ輻射強度を大きく見積もるため, 輻 射加熱率の評価という点では安全側の条件となっている.

2.4 輻射解析モデル 輻射解析は SPRADIAN version 1.5-PL4 を用いて行った ${ }^{32,33)}$. SPRADIAN は再突入物体 周りの輻射環境を総合的に解析できるパッケージであり，気 体の放射係数や吸収係数を計算するだけでなく, 輻射輸送 や壁面輻射加熱率の計算を行うことができる . MUSES-C の再突入環境では, 輻射が流れ場に及ぼす影響は小さく, 輻 射場と流れ場の連成を考慮して計算された機体の輻射加熱 率は, 流れ場から一意的に輻射強度を決定する非連成解析 の結果よりも小さい值を示すことが知られている ${ }^{5,8)}$. 従っ て本解析では, 計算コストを低減するとともに安全側の解 析を行うという立場から非連成解析を行った．

非連成輻射解析では，まず CFD 計算で得られた流れ場 の結果を用いて, 空気とアブレーション生成物の混合ガス の放射，吸収係数を全領域で計算する．次に，機体表面の 任意の位置における地平面上の立体角 $2 \pi$ の視野を 324 視 線方向に離散化し (方位方向に 36 分割, 迎角方向に 9 分 割), 各視線方向に輻射輸送方程式を積分して表面に到達す る輻射熱流束の総和を算出する.詳細は文献 33) の 4.5 節 を参照されたい. SPRADIAN-1.5-PL4 では， $\mathrm{C}_{3}$ の基底 準位からの連続およびバンド吸収, $\mathrm{C}_{2}$ の光電離反応に基 づく連続吸収が考慮されていない．これらは温度が低い壁 面近傍領域で，特に真空紫外から紫外の輻射を少なからず 吸収することが知られているが, 弚の温度依存性が不明確 なこともあり解析には取り込まれていない． MUSES-Cの 壁面輻射加熱は, 後述するように, 真空紫外から紫外領域 の寄与が大きいため，これらの吸収過程を無視したことで 輻射加熱率は過大評価されていると予想される .これは結 果的に安全側の解析を行うこととなり，本解析の目的に沿 うものである .

\section{3. 解 析 結 果}

3.1 淀み点加熱率の評価 CFD 解析により流れ場を決 定する方法は計算コストがかかるため, まず最初に経験式に 
第 1 表 $\mathrm{CFD}$ 解析に用いた再突入軌道上の飛行環境

\begin{tabular}{lrrrrrr}
\hline 時刻 $(\mathrm{s})$ & \multicolumn{1}{c}{59} & \multicolumn{1}{c}{64} & \multicolumn{1}{c}{69} & \multicolumn{1}{c}{74} & \multicolumn{1}{c}{79} & 84 \\
\hline 高度 $(\mathrm{km})$ & 72.59 & 64.05 & 56.17 & 49.29 & 43.76 & 39.72 \\
密度 $\left(10^{-3} \mathrm{~kg} / \mathrm{m}^{3}\right)$ & 0.06127 & 0.1871 & 0.4875 & 1.122 & 2.335 & 4.165 \\
温度 $(\mathrm{K})$ & 213.1 & 235.9 & 257.6 & 270.7 & 260.7 & 249.6 \\
対地速度 $(\mathrm{km} / \mathrm{s})$ & 12.18 & 11.87 & 11.08 & 9.541 & 7.324 & 5.061 \\
$\begin{array}{l}\text { Pyrolisys gas 吹出しレート } \\
\left(10^{-3} \mathrm{~kg} / \mathrm{s} \cdot \mathrm{m}^{2}\right)\end{array}$ & 32.2 & 34.3 & 34.4 & 31.6 & 27.3 & 20.5 \\
$\begin{array}{l}\text { カーボン曾質量損失レート } \\
\left(10^{-3} \mathrm{~kg} / \mathrm{s} \cdot \mathrm{m}^{2}\right)\end{array}$ & & & & & & \\
\hline
\end{tabular}

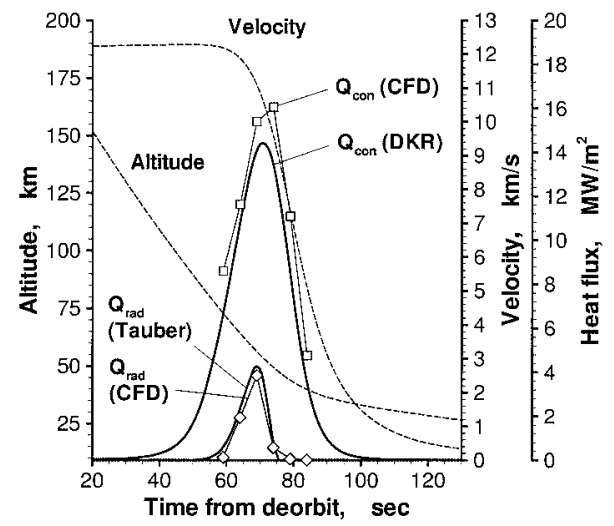

第 1 図 再突入軌道に沿った飛行高度, 速度, 淀み点加熱率の履歴

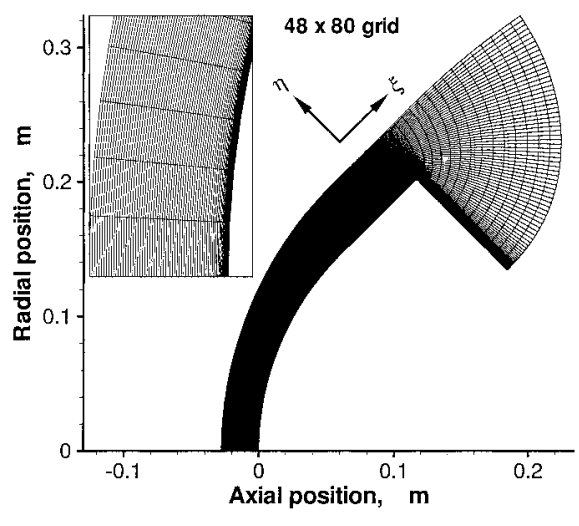

第 2 図 前面の加熱率解析に用いた計算格子
より再突入軌道に沿ったカプセル淀み点の加熱率の履歴を 計算し，CFD 解析の対象とすべき飛行条件を選定しておく． また, 経験式から得られる加熱率を CFD 解析結果と比較す ることで CFD 解析の妥当性を確認する.第 1 図に DetraKemp-Riddell ${ }^{34)}$ および Tauber ら ${ }^{35,36)}$ の経験式を用いて 計算した冷温壁加熱率 (cold-wall heat flux; CWHF) およ ひ輻射加熱率を，弚れ $Q_{\text {con }}(\mathrm{DKR}) ， Q_{\mathrm{rad}}$ (Tauber) で示す . 経験式による CWHF および輻射加熱率の最大值

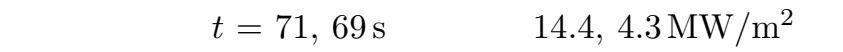
あり，再突入における対流加熱および輻射加熱総量は，光

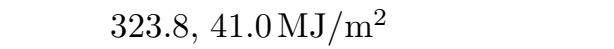

経験式を用いた加熱率の計算結果から , カプセルの加熱率 が大きくなると予想される再突入軌道上の 6 ケースを CFD 解析の対象として選定した. 第 1 表に光の飛行条件と，予 想されるパイロリシスガス吹出しレート, およびアブレー 夕質量損失レートを示す. カプセル淀み点の加熱率を精度 よく評価するために, 各ケースについてグリッドスタディ を行い，兰れ奖れ個別の計算格子を用いた．第 2 図に一例 として示したのは $t=69 \mathrm{~s}$ における計算格子である.グ リッドスタディの結果，このケースでは淀み点で壁面に垂 直な方向の最小格子幅は $16 \mu \mathrm{m}$ 程度以下であれば充分であ ることが分かっている．より高高度では密度が低下するた め最小格子幅はこれより大きくてもよく，逆に低高度では より小さい最小格子幅が必要となる。

まず CWHF を評価するために，アブレーションによる パイロリシスガスの吹出し量とカーボン層の質量損失レー 卜を 0 とし, 式 (2)で $\gamma=1.0$ (完全触媒壁) とし, 壁
面温度を全境界上で $T_{\mathrm{w}}=300 \mathrm{~K}$ として CFD 解析を行 い,さらに輻射解析を行った . 最終的に得られた淀み点で のCWHF と輻射加熱率を第 1 図に $Q_{\text {con }}$ (CFD) および $Q_{\mathrm{rad}}(\mathrm{CFD})$ として弚れ示す.解析結果は, CWHF に関しては $t=74 \mathrm{~s}$ で経験式の值より $9.2 \%$ 大きく, 輻射 加熱率に関しては $t=69 \mathrm{~s}$ で $11.5 \%$ 小さくなっているが， おおむね経験式とよい一致を示している.

この一致は, 衝撃層内で局所平衡状態が形成されている ことに由来している.第 3 図 a), b) は $t=69 \mathrm{~s}$ におけ る淀み点岐点流線上の温度分布および化学種の分布を光れ

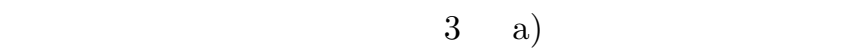
面から約 $7 \mathrm{~mm}$ 以内の距離ではほぼ局所熱平衡状態 (local thermal equilibrium ; LTE) となっていることが分かる LTE が形成されるということは, 衝撃波直後の熱的・化学 的非平衡性が CWHF に与える影響は小さく，CWHF の精 度は熱的・化学的非平衡モデルの不確実性よりは, むしろ 平衡定数や輸送係数の精度に依存すると考えられる. 事実, 非平衡モデルに対する CWHF の感度はほとんどないこと が分かった . Detra-Kemp-Riddellや Tauber の経験式は， 機体周りにLTE が形成される仮定のもとに導出されてお り，この仮定が成立するような場合は比較的精度のよい予 測値を与えることが実験的に確認されている ${ }^{35,36)}$. 以上の 事実から，MUSES-C 再突入環境を評価する上で経験式は 概ねよい予測を与え，また $\mathrm{CFD} /$ 輻射解析は妥当な精度を 有していると結論できる .

3.2 CFD によるカプセル全機体周りの加熱率の評価 次にカプセル全機体周りの加熱環境を解析するために, 計 算領域を機体の背面を含む領域まで拡張して $\mathrm{CFD} /$ 輻射解 


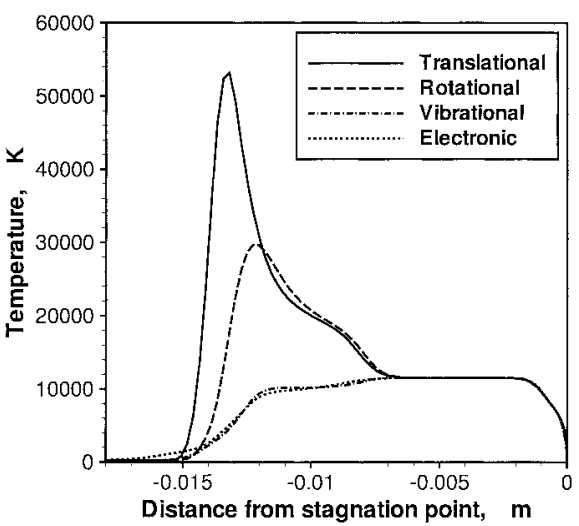

(a)

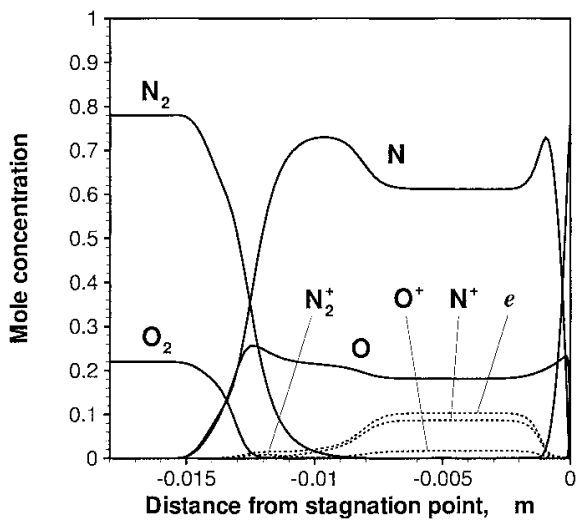

(b)

第 3 図 淀み点岐点流線上の a) 温度および b) 化学種の分布 : $t=69 \mathrm{~s}$

析を行った .ここで用いる新たな計算格子は, 前節で CFD により得られたカプセル前面での CWHF 分布が再現でき るように配置する必要がある．また文献 6) によると，機 体背面の輻射加熱率に対する計算領域打切りの影響が無視 できるためには, カプセル後方中心軸方向にカプセル半径 の 10 倍以上の計算領域を設ける必要がある . 後述するよ うに背面での対流加熱率は前面での弚れよりも桁違いに小 さく，また背面輻射加熱率と比較しても小さくなる一方で， 背面の格子幅を小さくすることは計算コスト増大や計算の 不安定化を招く場合がある .このため本稿では, 寄与の小 さい背面の対流加熱率の精度を犠牲にし $( \pm 50$ 100\%)，輻 射加熱率に影響がない範囲内て効率よい計算を行うことの できる格子を背面に用いる.以上の条件が満足されるよう に各 6 ケースについて光れ光れ格子を作成した . 第 4 図に $t=69 \mathrm{~s}$ の場合の計算格子を一例として示す .

まず全機周りの CWHF の分布を評価するために，前節 と同樣の壁面条件て解析を行った . 第 5 図に, 今回検討し たケースの中で最も総加熱率が大きくなる $t=69 \mathrm{~s}$ の場合 の全機体周りの対流加熱 $\left(Q_{\text {con }}\right)$ および輻射加熱 $\left(Q_{\mathrm{rad}}\right)$ の 分布を示す.ここで $S$ は淀み点から表面に沿って測った距 離， $R_{n}$ は鈍頭半径で $0.207 \mathrm{~m}$ である.対流加熱のうち， N やO などの中性活性種の壁面再結合による熱の放出が最も 大きく, 次いで並進モード, 分子の回転モード, 分子の振 動モードによる熱伝導の順となっている．イオンと電子の

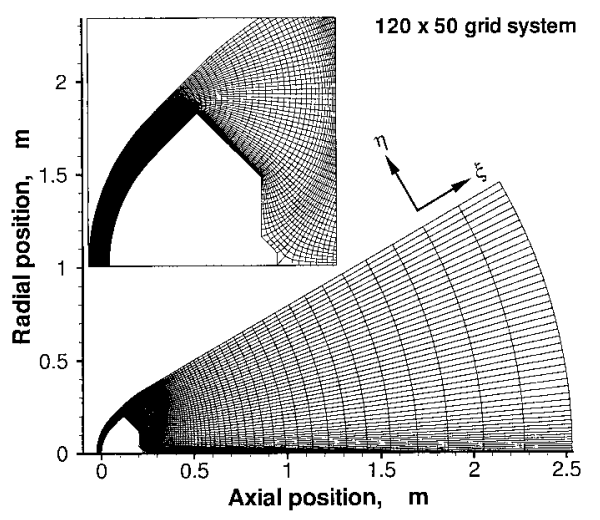

第 4 図 全機体周りの加熱率解析に用いた計算格子

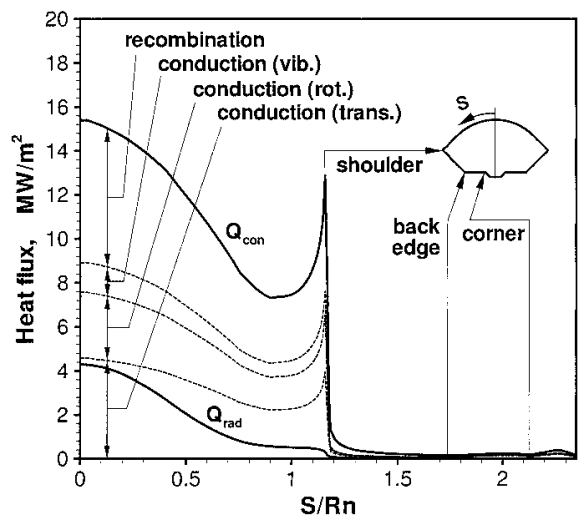

第 5 図 カプセル周りの加熱率分布 : $t=69 \mathrm{~s}, \gamma=1, T_{\mathrm{w}}=300 \mathrm{~K}$, without ablation

再結合はほとんど寄与しない .これは第 3 图 b) に示すよ うに，壁面近傍ではほとんど荷電粒子が存在しないからで ある. カプセルの背面では対流加熱率は急激に減少してい ることが分かる．また輻射加熱はアブレーションを考慮し ない場合，背面では無視できるほど小さい，

3.3 アブレーションが輻射加熱に与える影響 次にアブ レーションか輻射加熱率に与える影響を調べるために，第 1 表に示すパイロリシスガスの吹出しレートとカーボン層の 質量損失レートを与えて計算した .この解析ではアブレー ション生成物の 1) 緩和過程, 2) 輸送過程, 3) 化学反応過 程 ,4) 吹出しの絶対量に関する不確実性を考慮して, 以下 に示す幾つかのモデルについて計算を行った .

3.3.1 緩和モデルの影響 既に述べたように，本解析で 用いた緩和モデルは輻射強度が最大となるように選択した モデルであり，特に振動緩和については速い緩和モデルを 用いている .このベースモデルを Model A とし，振動緩 和についてより現実的な拡散モデル12,37) を用いたものを Model B とする. また，アブレーション生成物の緩和過程 の不確実性を考慮するため, 最もアブレーション生成物か らの輻射か溞くなる緩和過程を選択したものを Model C と する. Model C では, アブレーション生成物のうち分子の 回転, 振動モードが $300 \mathrm{~K}$ で涷結しているとし, 電子励起 については空気の電子励起と平衡状態にあると仮定したも のである .この組合わせにより，アブレーションガス分子 


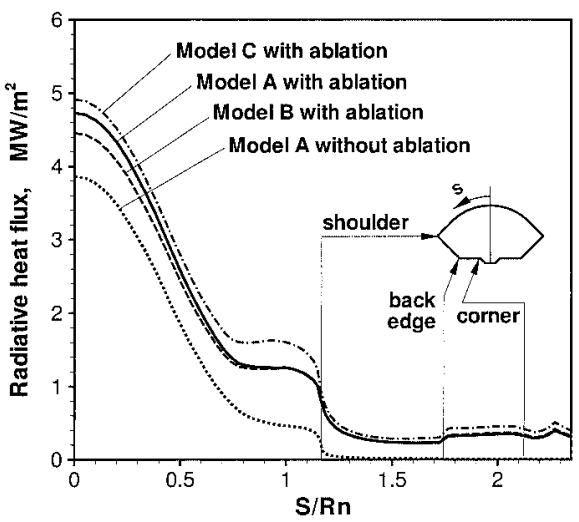

第 6 図 カプセル周りの輻射加熱率分布 $: t=69 \mathrm{~s}, T_{\mathrm{w}}=3,000 \mathrm{~K}$

の回転, 振動エネルギーが並進モードと電子励起モードに 再配分されるため，結果的に輻射強度は強くなる．ただし 放射, 吸収係数の算出においては, 空気種の回転, 振動温 度を用いて, さらに輻射強度が過大評価されるように計算 した . また $T_{\mathrm{w}}=3,000 \mathrm{~K}$ および $\gamma=0$ とした .これら の条件は輻射強度が高く評価されるように選択したもので， $T_{\mathrm{w}}$ を高くすることでアブレーションガスの温度を高くし， アブレーション生成物に関して非触媒条件を用いることで， 主要な発光種である $\mathrm{C}$ や $\mathrm{C}_{2}$ のモル分率を上昇させること を目的としている .

第 6 図に, $t=69 \mathrm{~s}$ の飛行条件で各モデルにより計算され た機体周りの輻射熱流束の分布を示す．比較のため，アブ レーションがないとした場合の輻射熱流束も図に示した .こ の結果から，アブレーションを考慮することて輻射加熱率が 大きく増加することが分かる.アブレーションの輻射加熱率 に与える影響は, カプセル前面のみならず，肩 (shoulder) から背後の領域に至るまで及んでいる．アブレーションが ないとした場合カプセル背面での輻射加熱率は著しく小さ いが $\left(0.01 \sim 0.1 \mathrm{MW} / \mathrm{m}^{2}\right)$, Model A でアブレーションを 考慮した場合, 肩て約 $0.7 \mathrm{MW} / \mathrm{m}^{2}$, 背面で約 $0.4 \mathrm{MW} / \mathrm{m}^{2}$ の輻射加熱が予測される .これらの值は淀み点輻射加熱率

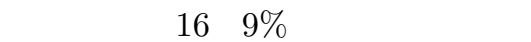

アブレーションを考慮した場合の輻射加熱率の増加は, 主 として二つの効果に由来している. 第 1 には, 吹出しによ る衝撃波離脱距離の増加であり, これは鈍頭半径の増加と 等価である.第 2 には，吹き出したアブレーション生成物 が衝撃層内の高温空気からの熱伝導で高温となり発光する， という効果によるもので, これは本質的に衝撃層厚みの増 加と等価である . 前面での輻射加熱率の増加は上の二つの 効果が同時に寄与しており，一方背後での輻射加熱率の増 加は，後述するようにアブレーション生成物からの輻射の 寄与による.

輻射加熱率の分布は, アブレーション生成物の熱的緩和 過程には光れほど敏感ではない，顕著な差が見られるのは カプセル前面の $S / R_{n}=0.7$ から肩領域で, Model C の 予測は他のモデルより約 30\% 大きくなっている .この領域 では, 吹き出されたアブレーション生成物がカプセル表面

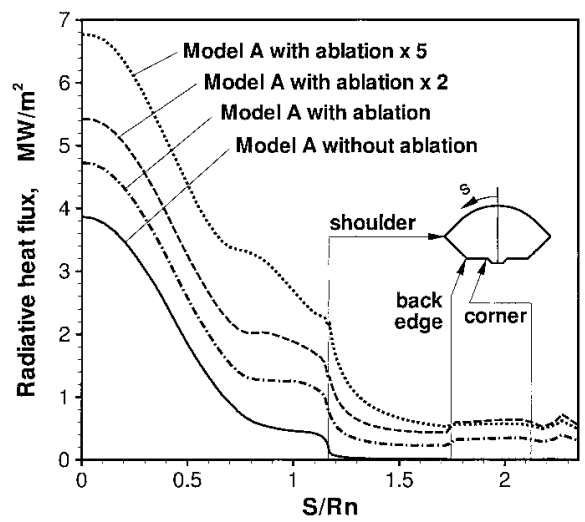

第 7 図 輻射加熱率に与える吹出し量の影響: $t=69 \mathrm{~s}, T_{\mathrm{w}}=3,000 \mathrm{~K}$

に沿って下流に流れるまでに充分な時間を要するため，電 子励起温度の分布が緩和モデルに影響を受けるためである カプセルの背面でも緩和モデルの違いによる影響か認めら れるが, 輻射強度のモデル間の差の絶対量は $0.1 \mathrm{MW} / \mathrm{m}^{2}$ 程度と小さい .

3.3.2 吹出し 量による影響 次にアブレーション生成物 の主流への拡散過程や, 吹出しの機構の不確実性を考慮す るために, 吹出しの絶対量を変化させて解析を行った . こ の解析では Model A を用い, カーボン層の質量損失レー トをノミナルの場合の 2 倍，5 倍とした場合について解析 を行った . 他の条件は前節の場合と同じである .一例とし $\tau t=69 \mathrm{~s}$ の飛行条件における結果を第 7 図に示す. 機体 周りの輻射加熱率は吹き出しの絶対量に大きく依存するこ とが分かる . 吹出し量の増加とともに輻射加熱率が増加す るのは, 衝撃波離脱距離か増加する効果と, 発光体となる アブレーション生成物か増加するという相乗効果によるも のであるが，吹出し量の増加とともに前面では前者の効果 が強く，逆に背面では後者が支配的となる．しかし過度の 吹出しに対してはカプセル背面のガスの温度が極端に低下 するため, 逆に背面での輻射強度は減少するようになる．

3.3.3 アブレーションによる流れ場と輻射場の変化 よ り詳しい議論をするために, アブレーション吹出し量に対 して流机場と輻射場がどのように変化するかを調べた．ア ブレーションがある場合は, 前面の壁面近傍に存在する比 較的低温のアブレーションガスが背面に回り込んでくる効 果と，雰囲気中に存在する $\mathrm{C}_{2}$ や $\mathrm{C}_{3}$ の解離による吸熱の ため, 背面での重粒子の並進温度や電子温度は吹出しがな い場合よりも一般に低くなる．これにも関わらずアブレー ションがある場合に背面の輻射加熱率が上昇するのは, 発 光する化学種がアブレーションの有無により異なるためで ある.このことを示すために, 肩 $\left(S / R_{n}=1.17\right)$ と背面 の中心軸上 $\left(S / R_{n}=2.34\right.$; 以下 base と呼引゙）の壁面上に 到達する輻射熱流束のスペクトルを第 8 図に示した . アブ レーションがある場合, C の線スペクトルと連続スペクト ル， $\mathrm{C}_{2}$ のバンドスペクトル，および $\mathrm{CO}$ のバンドスペク トルが全輻射強度に大きく寄与している.特に base では真 空紫外領域からの輻射か弱くなっているため, $\mathrm{C}_{2}$ のバンド 


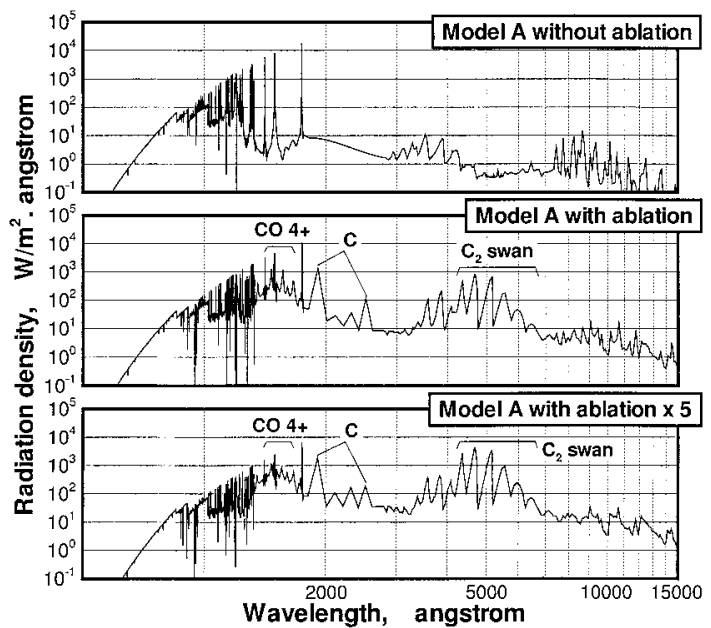

(a)

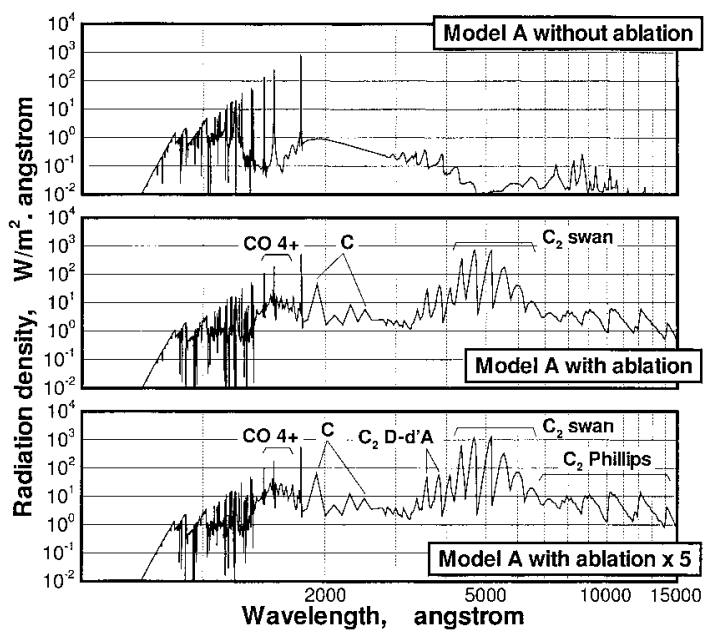

(b)

第 8 図 輻射強度スペクトル分布: $\mathrm{a})$ 肩 $\left(S / R_{n}=1.17\right)$, b) 背面の中 心軸上 $\left(S / R_{n}=2.34\right) ;$ Model A , $t=69 \mathrm{~s}, T_{\mathrm{w}}=3,000 \mathrm{~K}$

スペクトルが全輻射強度に占める割合は高くなっている．

背面での主要な発光種である $\mathrm{C}$ おび $\mathrm{C}_{2}$ の分布を第 9 図に示す . カプセルの肩から背後にかけて広い領域で $\mathrm{C} や$ $\mathrm{C}_{2}$ のモル分率は高くなっており, 特に $\mathrm{C}$ は広い範囲に高い 濃度で分布している.これは， $\mathrm{C}_{2}$ や $\mathrm{C}_{3}$ の解離エネルギー が $\mathrm{N}_{2}$ と比較して小さい (基底準位からの解離エネルギー はそれ光れ約 $70,930,87,480,113,200 \mathrm{~K})$ ために，比較的 低温度でも $\mathrm{C}$ は原子状態で存在できるからである． $\mathrm{C}_{2}$ は 可視領域に強いバンドスペクトルを持っており, 乥れらの 上準位のエネルギーが低いため非常に発光しやすい特性を 有している (例えば $\mathrm{C}_{2} \mathrm{Swan}$ バンドの上準位である $d^{3} \Pi_{g}$ の励起エネルギーは $28,808 \mathrm{~K}$ であるのに対し， $\mathrm{N}_{2}$ では第 1 励起準位である A ${ }^{3} \Sigma_{u}^{+}$でも $72,231 \mathrm{~K}$ である). 同樣に， $\mathrm{N}$ では強い発光を持つ線スペクトルの上準位が $120,000 \mathrm{~K}$ 程度のエネルギーから現われる（例えば $2 s^{2} 2 p^{2} 3 s{ }^{4} \mathrm{P}$ ) の に対し，Cでは $90,000 \mathrm{~K}$ 程度のエネルギーから現われる

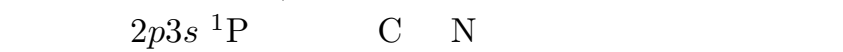
を放つ. 以上の理由から炭素系アブレーション生成物は発

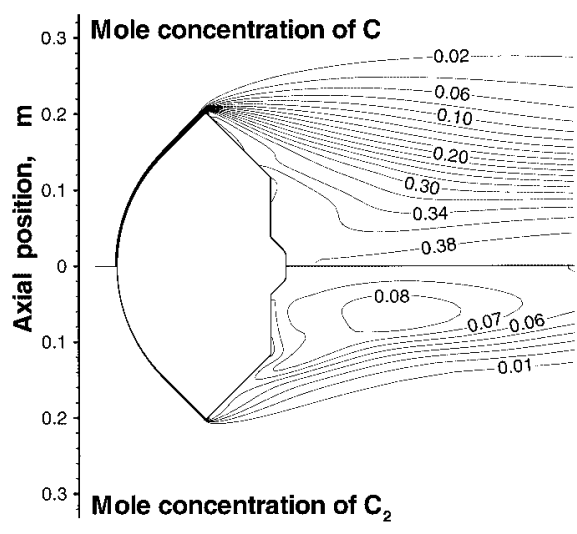

第 9 図 カプセル回りの $\mathrm{C}$ および $\mathrm{C}_{2}$ のモル分率の分布 : Model A， $t=69 \mathrm{~s}, T_{\mathrm{w}}=3,000 \mathrm{~K}$

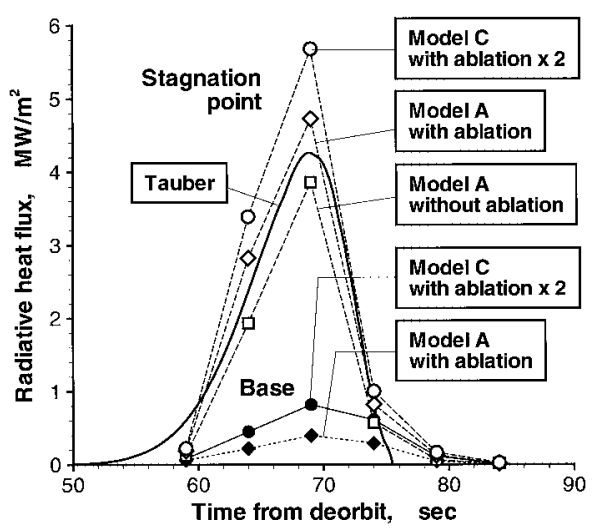

第10 図 淀み点と背面の中心軸上 (base) の輻射加熱率の履歴

光しやすく, 背面の輻射加熱率の増加に大きく寄与するの である

最後に，幾つかのモデルを用いて計算した淀み点と base の輻射加熱率の履歴を第 10 図に比較する . カーボン層の質 量損失レートの予測精度の誤差はたかだか $50 \%$ と考えられ ており，最も輻射加熱率が大きくなるモデルとして Model $\mathrm{C}$ でカーボン層の質量損失レートがノミナルの場合の 2 倍と なるものを選択した .この結果によれば, 淀み点の最大輻射 加熱率としては最大で 5.7 , ノミナルで $4.7 \mathrm{MW} / \mathrm{m}^{2}$ と考え ればよい. Base の最大輻射加熱率はアブレーションの吹出 し量に強く依存し, 最大で 0.82 , ノミナルで $0.40 \mathrm{MW} / \mathrm{m}^{2}$ 程度と予測できる. 淀み点の輻射加熱率は $t=69 \mathrm{~s}$ 以降は 急激に減少しているが, base の炎れは緩やかに減少してい るに過ぎない．この理由は，対流加熱率が $t=71 \mathrm{~s}$ 辺りで

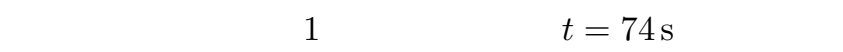
のアブレーションが起こっているためである .

\section{4. 結論}

工学的な立場から MUSES-C 再突入カプセル全機体周り の輻射加熱環境を総合的に評価することを目的とし，CFD 解析と輻射解析を行った . カプセルの再突入環境において は, 加熱率が最大となる $t=70 \mathrm{~s}$ 前後で衝撃層内に既に局 所熱平衡領域が形成され, CFD モデルに含まれる熱的・化 
学的非平衡モデルの差異がカプセル淀み点の CWHF に与 える影響は小さく，経験式はよい予測を与える . 淀み点と 比較し, 背面の CWHF や輻射加熱率は著しく小さい．

しかし機体周りの輻射加熱率は, CFD の熱的緩和過程に 弱く依存し，アブレーション吹出し量の増加とともに急激 に増加する . 吹出し量の増加とともに加熱率が増加するの は, 衝撃波離脱距離か増加する効果と, 発光体となるアブ レーション生成物が増加するという相乗効果によるもので あり，カプセル前面では前者の効果が強く，逆に背面では 後者が支配的である. 背面の輻射加熱率の増加に寄与して いるのは, 主として C と $\mathrm{C}_{2}$ である .これは $\mathrm{C}$ と $\mathrm{C}_{2}$ が比 較的低温から発光するという特性に起因する.

今回解析を行った飛行経路角 $-12.0 \mathrm{deg} の$ 再突入軌道 については，CWHF の最大值は淀み点で約 $16 \mathrm{MW} / \mathrm{m}^{2}$, baseで $0.3 \mathrm{MW} / \mathrm{m}^{2}$ と予想される. また輻射加熱の最大値 は, 淀み点で約 $5.7 \mathrm{MW} / \mathrm{m}^{2}$, base で $0.82 \mathrm{MW} / \mathrm{m}^{2}$ を越 えないと考えられる . カプセル背面の輻射加熱率はアブレー ション吹出し量に強く依存するため，注意が必要である．

\section{参 考 文 献}

1) 宇宙科学研究所 : MUSES-C 計画概要, 宇宙科学研究所, 2000.

2) Fujita, K., Sato, S., Abe, T. and Ebinuma, Y.: Experimental Investigation of Air Radiation from behind a Strong Shock Wave, J. Thermophys. Heat Transfer, 16 (2002), pp. 77-82.

3) Otsu, H., Fujita, K., Suzuki, K. and Abe, T.: Radiative Heating Analysis around the MUSES-C Reentry Capsule at Superorbital Speed, AIAA Paper 98-2447, 1998.

4) Otsu, H., Suzuki, K., Fujita, K. and Abe, T.: Effect of Ablative Gas on the Radiative Environment around the MUSESC Reentry Capsule, AIAA Paper 99-3463, 1999.

5) Suzuki, T., Furudate, M. and Sawada, K.: Unified Calculation of Hypersonic Flowfield for a Reentry Vehicle. J. Thermophys. Heat Transfer, 16 (2002), pp. 94-100.

6) 大津広敬 : 超軌道速度飛行体の輻射加熱環境に関する研究, 学位 論文, 東京大学大学院, 1999 .

7) 鈴木宏二郎 : 再突入カプセルにおけるアブレーションと化学非平 衡衝撃層流れの連製解析, 日本航空宇宙学会誌, 50 (2002), pp. 133-139.

8) Hartung, L. C.: Development of a Nonequilibrium Radiative Heating Prediction Method for Coupled Flowfield Solutions, J. Thermophys. Heat Transfer, 6 (1992), pp. 618-625.

9) Huber, P. W., Akey, N. D., Croswell, W. F. and Swift, C. T.: The Entry Plasma Sheath and Its Effects on Space Vehicle Electromagnetic Systems, NASA SP-252, 1971, pp. 219-358.

10) Gnoffo, P. A., Gupta, R. N. and Shinn, J. L.: Conservation Equations and Physical Models for Hypersonic Air Flows in Thermal and Chemical Nonequilibrium, NASA TP-2867, 1989.

11) Gupta, R. N., Yos, J. M., Thompson, R. A. and Lee, K. P.: A Review of Reaction Rates and Thermodynamic and Transport Properties for an 11-Species Air Model for Chemical and Thermal Nonequilibrium Calculations to 30,000 K, NASA RP-1232, 1990.

12) Park, C.: Nonequilibrium Hypersonic Aerothermodynamics, John Wiley \& Sons, New York, 1990.

13) Park, C.: Review of Chemical-Kinetic Problems of Future NASA Missions, I: Earth Entries, J. Thermophys. Heat Transfer, 7 (1993), pp. 385-398.

14) Sharma, S. P. and Gillespie, W.: Nonequilibrium and Equilibrium Shock Front Radiation Measurement, J. Thermophys. Heat Transfer, 5 (1991), pp. 257-265.

15) Fujita, K., Sato, S., Abe, T. and Otsu, H.: Electron Density Measurements behind Strong Shock Waves by H Beta Pro- file Matching, J. Thermophys. Heat Transfer, 17 (2003), pp. 210-216.

16) Furudate, M. and Sawada, K.: Effect of Rotational Nonequilibrium on Shock Standoff Distances in Intermediate Hypersonic Range, AIAA Paper 01-0813, 2001.

17) Yamada, T., Inatani, Y., Honda, M. and Hirai, K.: Development of Thermal Protection System of the MUSES-C/DASH Reentry Capsule, Acta Astronaut. 51 (2002), pp. 63-72.

18) Fujita, K. and Abe, T.: Assessment of Rotational Nonequilibrium Impact on the Aerodynamic Heating Rate, AIAA Paper 2000-2588, 2000.

19) Fertig, M., Dohr, A. and Fruhauf, H. H.: Transport Coefficients for High Temperature Nonequilibrium Air Flows, AIAA Paper 98-2937, 1998.

20) Parker, J. G.: Rotational and Vibrational Relaxation in Diatomic Gases, Phys. Fluids, 2 (1959), pp. 449-462.

21) Mertens, J. D.: Computational Model of Nitrogen Vibrational Relaxation by Electron Collisions, J. Thermophys. Heat Transfer, 13 (1999), pp. 204-209.

22) Lumpkin III, F. E., Chapman, D. R. and Park, C.: A New Rotational Relaxation Model for Use in Hypersonic Computational Fluid Mechanics, AIAA Paper 89-1737, 1989.

23) Lordi, J. A. and Mates, R. E.: Rotational Relaxation in Nonpolar Diatomic Gases. Phys. Fluids, 13 (1970), pp. 291-308.

24) Boyd, I. D.: Assessment of Chemical Nonequilibrium in Rarefied Hypersonic Flow. AIAA Paper 90-0145, 1990.

25) Fujita, K., Sato, S. and Abe, T.: Transient Temperatures and Electron Density Measurement behind Strong Shock Waves, Proc. of the 22nd International Symposium on Shock Waves, Vol. 1, 1999, pp. 825-830.

26) Otsu, H., Kanai, N., Fujita, K. and Abe, T.: Effect of Models for Transport Properties on the Hypersonic Reentry Heating Environment, AIAA Paper 2001-2831, 2001.

27) Hirschfelder, J. O., Curtiss, C. F. and Bird, R. B.: Molecular Theory of Gases and Liquids, John Wiley \& Sons, New York, 1954, Chapter 7.

28) Devoto, R. S.: Transport Properties of Ionized Monatomic Gases, Phys. Fluids, 9 (1966), pp. 1230-1240.

29) Brokaw, R. S.: Approximate Formulas for the Viscosity and Thermal Conductivity of Gas Mixtures, J. Chem. Phys., 29 (1958), pp. 391-397.

30) Capitelli, M., Gorse, C., Longo, S. and Giordano, D.: Transport Properties of High Temperature Air Spacies, AIAA Paper 98-2936, and erratta (distributed with the original paper at 7th AIAA/ASME Joint Thermophysics and Heat Transfer Conference), 1998.

31) Yamada, T., Hiyoshi, I. and Inatani, Y.: Effect of the Internal Pyrolysis Gas Pressure on Ablator Performance, Proc. of 22nd International Symposium on Space Technology and Science, Vol. 1, 2000, pp. 1029-1034.

32) Fujita, K. and Abe, T.: SPRADIAN, Structured Package for Radiation Analysis : Theory and Applications, ISAS Report No. 669, The Institute of Space and Astronautical Science, 1997.

33) 藤田和央: SPRADIAN version 1.5 USERS マニュアル 2.3 版 (PL3 対応), http://kazuland.eng.isas.ac.jp/SPRADIAN, 2000 .

34) Detra, R. W., Kemp, N. H. and Riddell, F. R.: Addendum to 'Heat Transfer to Satellite Vehicles Re-Entering the Atmosphere,' Jet Propulsion, 27 (1957), pp. 1256-1257.

35) Tauber, M. E., Bowles, J. V. and Yang, L.: Use of Atmospheric Braking during Mars Missions. J. Spacecraft Rockets, 27 (1990), pp. 514-521.

36) Tauber, M. E. and Sutton, K.: Stagnation-Point Radiative Heating Relations for Earth and Mars Entries, J. Spacecraft Rockets, 28 (1991), pp. 40-42.

37) Park, C.: Assessment of Two-Temperature Kinetic Model for Dissociating and Weakly-Ionizing Nitrogen, J. Thermophys. Heat Transfer, 2 (1988), pp. 8-16. 